\title{
Widows in Eighteenth-century Romania: A Review Article of New Books by Răsuceanu and Vintilă-Ghiţulescu
}

\author{
Silvia Dumitrache \\ Center of Excellence in the Study of Image Bucharest
}

Follow this and additional works at: https://docs.lib.purdue.edu/clcweb

Part of the Comparative Literature Commons, and the Critical and Cultural Studies Commons

Dedicated to the dissemination of scholarly and professional information, Purdue University Press selects, develops, and distributes quality resources in several key subject areas for which its parent university is famous, including business, technology, health, veterinary medicine, and other selected disciplines in the humanities and sciences.

CLCWeb: Comparative Literature and Culture, the peer-reviewed, full-text, and open-access learned journal in the humanities and social sciences, publishes new scholarship following tenets of the discipline of comparative literature and the field of cultural studies designated as "comparative cultural studies." Publications in the journal are indexed in the Annual Bibliography of English Language and Literature (Chadwyck-Healey), the Arts and Humanities Citation Index (Thomson Reuters ISI), the Humanities Index (Wilson), Humanities International Complete (EBSCO), the International Bibliography of the Modern Language Association of America, and Scopus (Elsevier). The journal is affiliated with the Purdue University Press monograph series of Books in Comparative Cultural Studies. Contact: <clcweb@purdue.edu>

\section{Recommended Citation}

Dumitrache, Silvia. "Widows in Eighteenth-century Romania: A Review Article of New Books by Răsuceanu and VintilăGhiţulescu." CLCWeb: Comparative Literature and Culture 13.1 (2011): <https://doi.org/10.7771/1481-4374.1719>

This text has been double-blind peer reviewed by $2+1$ experts in the field.

The above text, published by Purdue University Press @Purdue University, has been downloaded 357 times as of $11 /$ $07 / 19$.

This document has been made available through Purdue e-Pubs, a service of the Purdue University Libraries. Please contact epubs@purdue.edu for additional information.

This is an Open Access journal. This means that it uses a funding model that does not charge readers or their institutions for access. Readers may freely read, download, copy, distribute, print, search, or link to the full texts of articles. This journal is covered under the CC BY-NC-ND license. 


\section{PURDUE}

UNIVERSITY PRESS <http://www.thepress.purdue.edu>

\section{CLCWeb: Comparative Literature and Culture}

ISSN 1481-4374 <http://docs.lib.purdue.edu/clcweb> Purdue University Press (CPurdue University

CLCWeb: Comparative Literature and Culture, the peer-reviewed, full-text, and open-access learned journal in the humanities and social sciences, publishes new scholarship following tenets of the discipline of comparative literature and the field of cultural studies designated as "comparative cultural studies." In addition to the publication of articles, the journal publishes review articles of scholarly books and publishes research material in its Library Series. Publications in the journal are indexed in the Annual Bibliography of English Language and Literature (Chadwyck-Healey), the Arts and Humanities Citation Index (Thomson Reuters ISI), the Humanities Index (Wilson), Humanities International Complete (EBSCO), the International Bibliography of the Modern Language Association of America, and Scopus (Elsevier). The journal is affiliated with the Purdue University Press monograph series of Books in Comparative Cultural Studies. Contact: <clcweb@purdue.edu>

Volume 13 Issue 1 (March 2011) Book Review Article Silvia Dumitrache, "Widows in Eighteenth-century Romania: A Review Article of New Books by Răsuceanu and Vintilă-Ghiţulescu" $<$ http://docs.lib.purdue.edu/clcweb/vol13/iss1/14>

Contents of CLCWeb: Comparative Literature and Culture 13.1 (2011)

<http://docs.lib.purdue.edu/clcweb/vol13/iss1/> 
Silvia Dumitrache, "Widows in Eighteenth-century Romania:

A Review Article of New Books by Răsuceanu and Vintilă-Ghiţulescu"

page 2 of 5

CLCWeb: Comparative Literature and Culture 13.1 (2011): <http://docs.lib.purdue.edu/clcweb/vol13/iss1/14>

\section{Silvia DUMITRACHE}

\section{Widows in Eighteenth-century Romania:}

\section{A Review Article of New Books by Răsuceanu and Vintilă-Ghiţulescu}

Being a woman in patriarchal societies meant struggling for earning and maintaining an honorable position and, at the same time, it involved a restrictive spectrum of choices and freedom. Regardless of the age or the social status, a woman stumbled upon the same rigid conventions of the time. One of the most difficult position for a woman in eighteenth-century Romania was being a widow. In this article, I review Andreea Răsuceanu's book Cele două Mântulese (The Two Mântuleasas) and Constanţa Vintilă-Ghiţulescu's Focul amorului. Despre dragoste şi sexualitate în societatea românească 17501830 (The Fire of Love: Love and Sexuality in Romanian Society 1750-1830).

The condition of the widow represent a significant aspect of the society the two authors analyze, impossible to avoid when speaking about the private and the public sphere of the period. Răsuceanu and Vintilă-Ghiţulescu choose two different ways of tackling this aspect. In addition to the widow, Vintilă-Ghiţulescu takes into discussion the entire category of love and sexuality, with all that it entails: seduction, arranged marriages, the relationship between sexuality and sin, the role of the Church and of the Court in solving various arguments concerning marriage and dowry, rape, homosexuality (among lay people and the clergy). On the other hand, Răsuceanu, having as a starting point a particular case of two women, Stanca and Maria, the wife and the sister of a wealthy trader, Manta, develops her study into a more general consideration of the way the mentalities and the judiciary system of the age shaped widows' destiny. If Vintilă-Ghiţulescu starts from the general to particular, Răsuceanu chooses the opposite path: having the intention to write the history of the famous Mântuleasa Street, endowed with a mythical aura by Mircea Eliade in his fantastic stories where the street becomes the place in which the sacred and the profane meet, Răsuceanu discovers that Mântuleasa street had been, indeed, during the centuries, the host of picturesque characters and among them, the Manta family. Mântuleasa Street, part of the Mântuleasa slum is a central area of the capital city which represented the nucleus of the development of what would become modern Bucharest, is relevant, as Răsuceanu suggests, not only for the interesting and passionate case of Stanca and Maria, but also for several writings of Eliade (227). Eliade, renowned for his scientific writings such as The History of Religions was also a fiction writer innovating Romanian fantastic literature, based, until then mostly on folkloric elements. Eliade established a new direction endowing Romanian fantastic literature with a mythological perspective. A relevant element within this direction in Eliade's focus on the idea that even the most profane space can hide something sacred and mythological, provided that people are willing to see the signs. Mântuleasa street, Popa Soare, or Pache Protopopescu were inhabited in the eighteenth century by wealthy traders and had architectural features that would later recur in Eliade's stories. The existence of numerous wine cellars, owing to the fact that Bucharest represented an important wine-growing center (91), these cellars, became, in the twentieth century, a deserted space, bearing various "signs," intriguing as "heteroclite fragments, dampness tokens, scattered images, mysterious slits that can be understood only by the initiated ones" $(19,228)$.

With the same passion for Mântuleasa Street and for the mysteries that could be hidden there, Răsuceanu casts upon Stanca, Maria, and Manta a mythical aura, comparing Manta, owing to his activity which involved much traveling, with Odysseus, while Maria and Stanca embody two facets of Penelope: the fierce Maria and the soft-hearted Stanca (71). The way the two women, who founded Mântuleasa Church, on the land given to Stanca as dowery, remained in history - Maria as the strong woman who was probably in control and Stanca as the weak one, always being in the shadows - intrigued Răsuceanu and made her question the mechanisms of an age in which the widow would not enjoy the comfort and the protection of the family, but would be subjected to all sorts of abuses. The starting point of Răsuceanu's inquiry the church's inscription: "This sacred and holy church, which praises St. Michael and Gabriel as titular saints, is built by Lady Maria, Trader Manta's sister, and by Lady Stanca, Master Manta's wife and it was built on the 25th of September, in the year of 1242, during Gligore Ghica's reign" (54). The hierarchy of the sisters is odd and this made Răsuceanu dig not 
Silvia Dumitrache, "Widows in Eighteenth-century Romania:

A Review Article of New Books by Răsuceanu and Vintilă-Ghiţulescu"

page 3 of 5

CLCWeb: Comparative Literature and Culture 13.1 (2011): <http://docs.lib.purdue.edu/clcweb/vol13/iss1/14>

only into the lives of the wealthy Manta family, but also into the customs of the age and into the history of one of the richest and most vivid areas in Bucharest.

The period the two authors discuss - the beginning of the eighteenth to the beginning of the nineteenth century -marked a significant change in the political and social structures: the country was no longer governed by voivodes (Slavic title that originally denoted the principal commander of a military force), but by Fanariotes (of Greek ascendancy), appointed by the Ottoman Empire, and the instability and the harsh economical measures became the most relevant characteristics of the age. Legislation had numerous deficiencies and was far from representing a stable and coherent system and the category of the widow was one of the most affected by this judiciary system. A widow's inheritance represented merely a third of the deceased's possessions - the so-called "trichotomy" ("trimirie"), according to which the deceased's possessions should be split between the widow, the deceased's family, and the poor. Răsuceanu explains that this practice had its roots into Roman law, which seemed to be in favor of the surviving husband. This rule changed in favor of the family of the deceased after the Constantinople Synod decision in 1305 (80). In the eighteenth century this was still a reality, despite the existence of several attempts to adjust the unprivileged situation of the widow. Violeta Barbu, in her study De bono coniugali, explains that even starting from the seventeenth century, people began issue testaments in order to protect the surviving wife and to discourage the proliferation of tribe-like families (158). Thus, law put the widow in an unfair position: normally, she should have earned a certain independence, especially a material one, and she should have been able to live under less constraints. On the contrary, the widow had to fulfill even more social conventions and had to fight for her rights and freedom. Dan Horia Mazilu speaks about a pseudo-freedom, as the coercions of a marriage were only replaced by even a worse servitude: the never ending struggle with a law that discriminated them and often threw them mercilessly in the hands of the relatives or in those of the deceased's debtors. A double standard was imposed on the widow: she had to be in charge of her deceased husband's affairs and debts, she alone had to struggle to keep the household steady, and to solve her husband's unfinished business, but, on the other hand, she was not given solid legal support and status. More, in the absence of a testament, the woman remained in a state of incertitude. Răsuceanu highlights the numerous obstacles set by the husband's relatives so that the wife would not receive her share, especially when she was childless. However, at times the widow would give up willingly her rights to the inheritance, thus avoiding all other sorts of obligations (83).

Răsucean's case study is an exemplification of the widow's unprivileged situation. Stanca, Manta's wife, should have been the first one mentioned in the Mântuleasa Church's inscription, but the battle for priority was won by her sister-in-law. Even if the foundation was cast at the desire of Manta and Stanca, the building was finalized after Manta's death, when his sister took over his responsibilities, as it is proven by the document according to which Maria and Stanca gave the land to the church and which seems to indicate Maria "as the real leader" (76). The fact that Maria, and not Stanca, gained the first mention in the inscription is an indication the situation of the widow: "not few are the cases when the wife has to face the danger of hopelessly being exposed to the greedy relatives" (86). Further, the said situation has its roots in the sixteenth to the seventeenth century: Răsuceanu highlights that the notion of "family" was constructed and practiced in a way where the blood relations always came first to the detriment of the in-laws, thus including the widow (66).

By the eighteenth century Romanian society experienced changes, and, more often than not, this new condition involved an elusive advantage, that of independence along with numerous disadvantages, especially when the deceased husband left behind debts and, besides that, not even having the presence of mind to draw up a testament in order to protect his wife from his relatives. This new aspect, considerably the most significant one for the situation of the widow is doubled by another aspect, which is brought into discussion by Vintilă-Ghiţulescu: the widow was not only the woman who had to face new and sometimes overwhelming responsibilities, but she also had a difficult position in what concerns future relationships. Focusing on the case of young widows, Vintilă-Ghiţulescu explains that the widow was seen as prey: "young, therefore a potential catch, both as an affair and as a potential marriage, widow, therefore free and unconstraint towards her sexual life, poor and often alone, without the support of the family ... The widow indulges herself more easily in a sexual relationship" (135). For obvious reasons, men saw the perspective of having a relationship with a widow more 
Silvia Dumitrache, "Widows in Eighteenth-century Romania:

A Review Article of New Books by Răsuceanu and Vintilă-Ghiţulescu"

page 4 of 5

CLCWeb: Comparative Literature and Culture 13.1 (2011): <http://docs.lib.purdue.edu/clcweb/vol13/iss1/14>

compelling, because the woman had sexual experience and so the man would not put himself in a great danger, legally speaking, as it would have been the case with a virgin. A sexual relationship with a virgin before marriage resulted in harsh punishment, because of the cross-cultural rule whereby a girl who lost her virginity lost, in fact, her honor.

Răsuceanu and Vintilă-Ghiţulescu discuss love, sex, and social and legal relationships in terms of economy - "to trade," "marketable," "supply and demand" - because people's private life was not private at all. The court and the church represented the "resorts" that intervened be it acts of seduction, kidnapping, or rape. Love became more of an institution than a personal, intimate choice: "Love is a blend between the priest, the protopopes, the magistrates, the ecclesiastic Court"'" (VintilăGhiţulescu 60). The right of choosing whom you like, with no consideration of the community's public opinion, was stultified as gossip and slander were more important than "true feelings" and could destroy any relationship. The judiciary system encouraged this kind of mixing between the public and the private as there were laws which provided for all sorts of disagreements and quarrels between the lovers. Thus, it was not just about an unwritten law, superstition, or mere habits, but legislation that punished any act that would evolve into "committing a sin." For men, among the punishments suffered by the seducer, in accordance with the gravity of his acts, included the loss of the wife's dowry, cutting off the nose, capital punishment, and public humiliation (Vintilă-Ghiţulescu 61). For women when a widow, in economy terms was on the "market," but her situation was more difficult, because the desire to remarry was perceived as condemnable and, once again, the law encouraged this perspective. The situation was not particular for Orthodox Christian Europe alone, but also for the Roman Catholics or Protestants: Răsuceanu mentions that remarriage was discouraged in general (67) and Mazilu highlights that the Roman Catholic Church believed that even if not prohibited, a second marriage was less honorable than widowhood (188). And Vintilă-Ghiţulescu frames the category of widowhood into the wider segment of "prohibited sexuality" along with "kidnapping," "rape," and "sodomy."

The injustice made to Stanca determined Răsuceanu to research the customs of the age in order to find hidden evidence left by women and she found this in Mântuleasa Church's frescos. One of them depicts two women, standing in front of a saint: the two women seem to be rich and a difference in age between them can be seen. It is a great chance that these two women represent the figures of Maria and Stanca, as it was a common practice in the age for the founders to stand as models for the figures painted in the narthex (100). The rest of the frescos have a highly allegorical structure, especially the animal allegory, "which serves as a guide for a good Christian, who should be able to unravel the stories and to understand what proper Christian behavior means" (106). Depictions of sin on the walls of the churches was common practice in the eighteenth century and Mântuleasa Church is no exception. But Răsuceanu identifies an element that singles out Mântuleasa Church, a specific depiction that is identifiable in this church, namely the sin of eavesdropping. Răsuceanu brings into discussion Grigore's of Măhaci's translation of the legend, in which it is made clear that the sinners are mostly women (123) and she concludes that this unique situation suggests that the fresco wascommissioned, and that, perhaps, it was an opportunity for Stanca to send a message about "her precarious situation within a community which equaled her condition of a widow with the very image of vulnerability" (122).

Răsuceanu and Vintilă-Ghiţulescu open the door to a fascinating age allowing us to take a glimpse into a world where love, hate, seduction, relationships, and the family were a significant aspect of people's lives but under the rules of social and legal constraints. Obviously, the recovery of that world cannot be complete and the two authors were aware of the fact that imagination must fill the void left by written sources. Vintilă-Ghiţulescu explains that "the world I am bringing back to life is, first of all, a world shaped according to the way I felt it and imagined it" (12). Imagination is an important recourse for Răsuceanu too, who admits that the study of the documents alone does not give an exhaustive image of an age and who employs her imagination to fill gaps (188). And, more than that, the reader is invited to step alongside the two authors in this passionate adventure.

\section{Works Cited}

Barbu, Violeta. De bono coniuagli (About Good Marriage). Bucharest: Meridiane, 2003. 
Silvia Dumitrache, "Widows in Eighteenth-century Romania:

A Review Article of New Books by Răsuceanu and Vintilă-Ghiţulescu"

page 5 of 5

CLCWeb: Comparative Literature and Culture 13.1 (2011): <http://docs.lib.purdue.edu/clcweb/vol13/iss1/14>

Mazilu, Dan Horia. Văduvele sau Despre istorie la feminin (Widows, or History from a Feminine Perspective). Iaşi: Polirom, 2008.

Răsuceanu, Andreea. Cele două Mântulese (The Two Mântuleasas). Bucharest: Vremea, 2009.

Vintilă-Ghiţulescu, Constanţa. Focul amorului. Despre dragoste şi sexualitate în societatea românească 1750-1830

(The Fire of Love: Love and Sexuality in Romanian Society 1750-1830). Bucharest: Humanitas, 2006.

Reviewer's profile: Silvia Dumitrache is working towards her doctorate at the Center of Excellence in the Study of Image (Bucharest), with a dissertation about 9/11 in literature and cinematography. She works as an editor at the weekly magazine Observator cultural for which writes book and theater reviews and interviews with artists and reports on cultural events. E-Mail: <silvia_dumitrache85@yahoo.com> 